\title{
Mandamus as a Remedy for the Denial of Jury Trial
}

\author{
Nathan A. Forrester $\dagger$
}

The Supreme Court has consistently stated that federal appellate courts may issue the writ of mandamus as an interlocutory remedy only under "extraordinary" circumstances, ${ }^{1}$ to correct a lower court order that is "not mere error but usurpation of power." The Court has explained that mandamus cannot serve as a substitute for normal appeal and should be available "only where appeal is a clearly inadequate remedy."

Nevertheless, most federal courts of appeals now routinely use mandamus to compel the lower court to conduct a jury trial. ${ }^{4}$ These appellate courts typically cite two Supreme Court decisions-Beacon Theatres, Inc. $v$ Westover ${ }^{5}$ and Dairy Queen, Inc. $v$ $W_{o o d}{ }^{6}$ - as authority for the proposition that the denial of a jury trial is not subject to the traditionally strict standards for the availability of mandamus. The Seventh Circuit alone has interpreted these decisions differently, holding that mandamus is the appropriate remedy only when the petitioner would be unable to appeal effectively the district court's denial of jury trial at the conclusion of the trial. ${ }^{7}$ Although it has had the opportunity, the Supreme Court has not yet resolved this circuit split. ${ }^{8}$

† B.S. 1988, University of Florida; J.D. Candidate 1992, The University of Chicago.

'Ex parte Fahey, 332 US 258, 260 (1947) ("As extraordinary remedies, they are reserved for really extraordinary causes.").

2 De Beers Consolidated Mines, Ltd. v United States, 325 US 212, 217 (1945).

3 Fahey, 332 US at 260. See also Roche v Evaporated Milk Ass'n, 319 US 21, 26-29 (1943); Allied Chemical Corp. v Daiflon, Inc., 449 US 33, 34-35 (1980) (per curiam).

- See, for example, In re Zweibon, 565 F2d 742 (DC Cir 1977); In re Union Nacional de Trabajadores, 502 F2d 113 (1st Cir 1974); Lee Pharmaceuticals v Mishler, 526 F2d 1115 (2d Cir 1975) (per curiam); Eldredge v Gourley, 505 F2d 769 (3d Cir 1974) (per curiam); General Tire \& Rubber Co. $v$ Watkins, 331 F2d 192 (4th Cir 1964); In re Pan-American Life Ins. Co., 188 F2d 833 (5th Cir 1951); Black v Boyd, 248 F2d 156 (6th Cir 1957); In re Vorpahl, 695 F2d 318 (8th Cir 1982); Mondor v U.S. Dist. Court for the Central Dist. of California, 910 F2d 585 (9th Cir 1990); Bruce v Bohanon, 436 F2d 733 (10th Cir 1970).

359 US 500 (1959).

- 369 US 469 (1962).

' First National Bank of Waukesha v Warren, 796 F2d 999, 1006 (7th Cir 1986).

- See Kamen $v$ Nordberg, 485 US 939 (1988) (White dissenting from denial of certiorari). 
This Comment aims to identify the circumstances under which a federal appellate court may issue mandamus as an interlocutory remedy to compel a district court to recognize a litigant's right to jury trial. Section I describes the two statutes that constitute the primary sources of authority for the availability of mandamus: the Final Decisions Rule ${ }^{9}$ and the All Writs Act. ${ }^{10}$ This Section notes that the Final Decisions Rule-which expresses the congressional policy in favor of appeal only after a final decision at trial-significantly limits the power that the All Writs Act grants to appellate courts to use mandamus as an interlocutory appellate remedy. Section I also reviews general Supreme Court doctrine on the availability of mandamus. Section II presents the five Supreme Court cases that have addressed the availability of mandamus to compel jury trial, and analyzes the various circuit court decisions that attempt to interpret these decisions. The lower courts have followed two basic approaches: the majority views the denial of jury trial as a "special circumstance," which per se justifies a mandamus remedy, while the Seventh Circuit limits the use of mandamus in the jury context to cases of "necessity," only granting mandamus when there is no other effective appellate remedy.

Section III argues that neither the majority nor the Seventh Circuit approach is consistent with Supreme Court precedent. The Comment concludes that the Supreme Court has not created a separate category for the right to trial by jury, and that the same categories of mandamus should therefore be available to remedy the denial of jury trial as to correct any other district court error. In addition to the traditional use of mandamus under conditions of necessity, to which the Seventh Circuit would limit the availability of mandamus, the Supreme Court has recognized the existence of "supervisory" and "advisory" strains of mandamus. By limiting mandamus as a remedy for the denial of jury trial to these alreadyrecognized categories, the proposed regime accommodates both the congressional policy disfavoring interlocutory appeals in the Final Decisions Rule and the discretion granted the appellate courts to issue mandamus under the All Writs Act.

\section{An Introduction to Mandamus}

In the First Judiciary Act of 1789, Congress laid down the general rule that litigants may appeal only the final decisions of dis-

- 28 USC § 1291 (1988).

10 Id at $\$ 1651$ (1988). 
trict courts. ${ }^{11}$ Federal courts and commentators have commonly understood that the purpose of this "Final Decisions Rule" is to avoid the piecemeal litigation of both civil and criminal claims in federal courts and to avoid the disruption and expense that would result from frequent interlocutory appeals. ${ }^{12}$ This rule, however, has a number of statutory and common law exceptions, ${ }^{13}$ one of which is the writ of mandamus. The All Writs Act, which also derives from the First Judiciary Act, ${ }^{14}$ authorizes the federal appellate courts to use mandamus as an interlocutory remedy. ${ }^{18}$ This statute imposes only very loose limitations on the availability of mandamus, however, and, for the most part, relies on the common

11 Id at $\$ 1291$. The Final Decisions Rule provides in relevant part: "The courts of appeals ... shall have jurisdiction of appeals from all final decisions of the district courts of the United States . . . except where a direct review may be had in the Supreme Court."

12 See, for example, Cobbledick v United States, 309 US 323, 325 (1940) ("Congress from the very beginning has, by forbidding piecemeal disposition on appeal of what for practical purposes is a single controversy, set itself against enfeebling judicial administration. Thereby is avoided the obstruction to just claims that would come from permitting the harassment and cost of a succession of separate appeals."); Will v United States, 389 US 90, 96 (1967) ("This general policy against piecemeal appeals takes on added weight in criminal cases, where the defendant is entitled to a speedy resolution of the charges against him."). For academic commentary on the Final Decisions Rule, see Carleton M. Crick, The Final Judgment as a Basis for Appeal, 41 Yale L J 539 (1932); Comment, The Use of Extraordinary Writs for Interlocutory Appeals, 44 Tenn L Rev 137 (1976).

${ }_{13}$ See, for example, 28 USC $\$ 1292$ (1988) (statutory exception that grants litigants the right to appeal certain interlocutory orders and grants appellate courts the discretion to hear appeals of certain other interlocutory orders); Cohen v Beneficial Industrial Loan Corp., 337 US 541, 546 (1949) (judicially created exception under which certain district court orders "which finally determine claims of right separable from, and collateral to, rights asserted in the action" are appealable). See also Cobbledick, 309 US at 324-25 ("Finality as a condition of review ... was written into the first Judiciary Act and has been departed from only when observance of it would practically defeat the right to any review at all.").

14 The All Writs Act had its genesis in $\S 13$ of the First Judiciary Act of 1789, 1 Stat 80, 81. See Marbury v Madison, 5 US 137 (1803).

1s The All Writs Act provides in relevant part: "The Supreme Court and all courts established by Act of Congress may issue all writs necessary or appropriate in aid of their respective jurisdictions and agreeable to the usages and principles of law." 28 USC $\S 1651$ (a). Congress passed this statute on June 25, 1948, consolidating and repealing three former provisions of the Judiciary and Judicial Procedure section of the United States Code. See 62 Stat 944 (1948).

The phrase "in aid of their respective jurisdictions" codifies the traditional limitation that mandamus must be an exercise of authority that is auxiliary to the court's independently existing jurisdiction. See Roche, 319 US at 25; In re Josephson, 218 F2d 174, 179-80 (1st Cir 1954). However, the Supreme Court has never required that mandamus be an exercise of jurisdiction "already acquired by appeal"; rather it has always permitted mandamus to "extend[] to those cases which are within [the court's] appellate jurisdiction although no appeal has been perfected." Roche, 319 US at 25; see also McClellan $v$ Carland, 217 US 268 (1910); Insurance Company v Comstock, 83 US 258 (1872). 
law to specify the conditions under which a court may grant a petition for the writ. ${ }^{16}$

The federal courts, then, have the task of resolving the tension between the All Writs Act and the Final Decisions Rule. The case law on mandamus is rife with maxims about when mandamus will issue. For instance, the Supreme Court has repeatedly stated that the appropriate use of mandamus by the appellate courts is "to confine an inferior court to a lawful exercise of its prescribed jurisdiction or to compel it to exercise its authority when it is its duty to do so."17 The federal courts, however, have typically applied a less than technical definition of what constitutes such a "jurisdictional" error. The Supreme Court has frequently held that mandamus will lie to correct not mere error but instead usurpation of power by a district court. ${ }^{18}$ Moreover, not just any "judicial usurpation of power" will merit the remedy of mandamus. The petitioner also has the "burden of showing that its right to issuance of the writ is 'clear and indisputable." "19

Such cliches provide little guidance as to when mandamus is an appropriate remedy. Without further limitations, any instance of a district court improperly rejecting a litigant's demand for jury trial could be construed as a usurpation of power justifying the issuance of the writ. Therefore, the most useful approach is to categorize the sorts of jurisdictional errors that the Supreme Court has historically recognized as worthy of the remedy of mandamus.

The Supreme Court has recognized essentially two categories of mandamus: mandamus under conditions of necessity, and mandamus under special circumstances. The paradigm necessity case is where the petitioner has no other effective means of relief from the

18 The phrase "agreeable to the usages and principles of law," which appeared in substantially the same form in two of the three predecessor provisions, indicates that Congress intended neither to displace the already developed common law standards for mandamus nor to preclude further development of these standards in the federal courts. Compare 64 Stat 944 (1948), with 36 Stat 1156 (1911); 36 Stat 1162 (1911).

${ }_{17}$ Bankers Life \& Casualty Co. v Holland, 346 US 379, 382 (1953) (quoting Roche, 319 US at 26). See also Allied Chemical, 449 US at 35; Will v Calvert Fire Insurance Co., 437 US 655, 661 (1978); Kerr $v$ U.S. Dist. Court for the Northern Dist. of California, 426 US 394, 402 (1976); Will $v$ United States, 389 US at 95; United States Alkali Export Ass'n, Inc. $v$ United States, 325 US 196, 202 (1945); Ex parte Republic of Peru, 318 US 578, 583 (1943).

18 De Beers Consolidated Mines, 325 US at 217. See also Note, Supervisory and Advisory Mandamus Under the All Writs Act, 86 Harv L Rev 595, 598-600 (1973).

18 Bankers Life \& Casualty, 346 US at 384 (quoting United States v Duell, 172 US 576, $582(1899))$. Whether the district court error is "clear and indisputable" is a separate issue from whether mandamus is an appropriate remedy in the first place. This Comment is only concerned with the latter issue, the propriety of mandamus for a given type of error. 
district court's error. ${ }^{20}$ The classic example is Maryland $v$ Soper (No. 1), ${ }^{21}$ in which the State of Maryland sought mandamus to vacate a federal district court order requiring the removal of a criminal prosecution from a Maryland court to a federal court. The State of Maryland was prosecuting federal prohibition agents for murder, but the agents claimed that they were entitled to federal jurisdiction because they had allegedly committed the murders in their capacity as federal agents. ${ }^{22}$ The Supreme Court granted mandamus to vacate the removal, noting that Maryland had no other effective remedy to force the district court to remand the indictment to the state court, because " $[t]$ he order of the United States District Judge refusing to remand is not open to review on a writ of error, and a judgment of acquittal in that court is final."23

The Supreme Court has often intimated that this condition of necessity constitutes the only situation for which mandamus is appropriate. ${ }^{24}$ The Final Decisions Rule provides the rationale for such a limitation. To grant mandamus to a petitioner who has an alternative avenue of appeal would "thwart the congressional policy against piecemeal appeals." ${ }^{25}$

This necessity rule has never been without its exceptions, however. Even prior to the expansion of the availability of mandamus in the late 1950s and early 1960s, the Supreme Court sometimes issued the writ under circumstances not constituting necessity but which the Court nonetheless deemed "special" and thus worthy of mandamus. ${ }^{28}$ For example, in Ex parte Republic of $P e r u,{ }^{27}$ the Supreme Court granted mandamus compelling the dis-

\footnotetext{
20 Roche, 319 US at $27-28$ ("Ordinarily mandamus may not be resorted to as a mode of review where a statutory method of appeal has been prescribed or to review an appealable decision of record.").

21270 US 9 (1926).

22 Id at 22.

23 Id at 30 .

34 See, for example, Allied Chemical, 449 US at 35; Thermtron Products, Inc. $v$ Hermansdorfer, 423 US 336, 352-53 (1976). For further historical examples of the "necessity" principle, see Bankers Life \& Casualty, 346 US at 383; Fahey, 332 US at 260; United States Alkali Export Ass'n, 325 US at 203; Roche, 319 US at 26-28; Ex parte Rowland, 104 US 604, 617 (1881).

${ }^{25}$ Parr v United States, 351 US 513, 520-21 (1956).

36 In Roche, the Supreme Court noted a number of prior Supreme Court cases that had granted mandamus under "special circumstances which would justify the issuance of the writ," although they did not constitute a condition of necessity. 319 US at 31 . These cases included McCullough $v$ Cosgrave, 309 US 634 (1940), in which the special circumstance was "the persistent disregard of the Rules of Civil Procedure"; and Ex parte United States, 287 US 241 (1932), in which the special circumstance was "the refusal to perform a plain ministerial duty."

27318 US 578.
} 
trict court to recognize the sovereign immunity of a vessel owned by the Peruvian government. Although the Court admitted that the foreign sovereign would still have the option to appeal its claim of sovereign immunity at the end of the trial, the Court concluded that this claim was one of "such public importance and exceptional character" as to justify issuing the writ. ${ }^{28}$ In short, the lack of another effective remedy for the district court error has historically provided a sufficient, but not a necessary, condition under which mandamus is an appropriate remedy. In the late 1950 s and early 1960s, the Supreme Court expanded the special circumstances category with two landmark decisions-La Buy v Howes Leather Co., Inc. ${ }^{2 \theta}$ and Schlagenhauf $v$ Holder. ${ }^{30}$ These two cases introduced the use of mandamus for supervisory and advisory purposes.

In $L a B u y$, the Supreme Court authorized a supervisory strand of mandamus to correct chronic abuses of discretion by a district court. ${ }^{31}$ The Court held that it was within the discretion of the Seventh Circuit to issue a writ of mandamus that would prevent the district court judge from using a special master to resolve a pair of antitrust cases. ${ }^{32}$ In so ruling, the Court rejected the argument that mandamus was inappropriate because the litigants could appeal the district court's use of a special master after the final judgment..$^{33}$ Instead, the Court particularly emphasized two facts that it found justified issuing mandamus in this case. The Seventh Circuit had repeatedly warned the district courts not to use special masters except in extreme cases, and, in spite of this admonition, the district court judge had referred eleven cases over a six year period to special masters. ${ }^{34}$ Thus, under these "exceptional circumstances" of chronic abuse, the Court concluded that mandamus was appropriate as an exercise of "supervisory control . . . necessary to proper judicial administration in the federal system."

Four years later, in Schlagenhauf, the Supreme Court recognized another advisory strand of mandamus, for use when deciding

\footnotetext{
28 Id at 586.

29352 US 249 (1957).

so 379 US 104 (1964).

32352 US at 259-60. See also Note, 86 Harv L Rev at 602-13 (cited in note 18); Comment, 44 Tenn $L$ Rev at 147-49 (cited in note 12).

${ }^{32}$ LaBuy, 352 US at 250-51.

ss Id at 254-55. The Supreme Court noted that " 'the common law writs, like equitable remedies, may be granted or withheld in the sound discretion of the court.' "Id at 255 (quoting Roche, 319 US at 25).

s4 Id at 258.

ss Id at $259-60$.
} 
"new and important problems of law."s6 A district court had ordered Schlagenhauf to submit to nine mental and physical examinations pursuant to Rule 35 of the Federal Rules of Civil Procedure. Schlagenhauf sought mandamus to overturn this order. ${ }^{37}$ Acknowledging that the writ of mandamus should not serve as a "substitute for appeal," the Court nonetheless ruled that mandamus was an appropriate remedy in this case. ${ }^{38}$ The Court emphasized that the district court's lack of power to order such examinations was "underscored by the fact that the challenged order requiring examination of a defendant appears to be the first of its kind in a reported decision in the federal courts under Rule 35 ."30 Thus, held the Court, the court of appeals below did in fact have the power to use mandamus to resolve this "issue[] of first impression" concerning the scope of Rule $35 .^{40}$

\section{The Use of Mandamus to Order Jury Trials}

Five Supreme Court decisions have specifically addressed the availability of mandamus as an interlocutory appellate remedy to compel jury trial. In each of these decisions, the Court approved such a use of mandamus; in none of them, however, did the Court provide much reasoning to justify its conclusion. Most courts of appeals have accordingly interpreted these Supreme Court decisions to allow the mandamus remedy whenever jury trial is denied, but the Seventh Circuit allows use of the writ only in cases of necessity.

\section{A. Supreme Court Decisions}

The first set of Supreme Court opinions on the use of mandamus to order jury trial includes Ex parte Simons, ${ }^{41}$ Ex parte Peterson, ${ }^{42}$ and Ex parte Skinner \& Eddy Corp., ${ }^{43}$ all decided prior to the passage of the All Writs Act in $1948 .{ }^{44}$ In Simons, the peti-

s6 379 US at 111. See also Note, 86 Harv L Rev at $613-19$ (cited in note 18).

37379 US at 108-09.

ss Id at 110.

s9 Id. The precise issues of first impression in Schlagenhauf were the interpretation of the "good cause" and "in controversy" requirements in FRCP 35. Id at 111.

10 Id.

11247 US 231 (1918).

42253 US 300 (1920).

43 265 US 86 (1924).

4 The First Circuit has argued that the 1948 All Writs Act narrowed the Supreme Court's power to issue mandamus by adding the limiting phrase that the federal courts could issue the writ only when "necessary or appropriate in aid of their respective jurisdic- 
tioner for mandamus had filed a civil action in two counts, the first of which the district court had transferred to the equity side of its docket. ${ }^{45}$ Thereafter the petitioner sought mandamus to compel the district court to resolve both counts with a jury trial. The Supreme Court, in an opinion by Justice Holmes, granted the petition for mandamus. ${ }^{46}$ Two years later, in Peterson, the Supreme Court affirmed Simons in dicta. ${ }^{47}$ Although the Court denied mandamus in Peterson on the grounds that the district court had not in fact denied the petitioner's right to a jury trial, the Court stated that mandamus would have been the appropriate remedy to compel jury trial. ${ }^{48}$ Finally, in Skinner \& Eddy, the Court cited both Simons and Peterson as authority for granting mandamus to compel the district court to issue an order of dismissal. ${ }^{49}$ The Court

tions." See In re Josephson, 218 F2d 174, 179 (1st Cir 1954). Prior to the All Writs Act, the Supreme Court had derived its power to grant mandamus from 28 USC $§ 342$, which did not include this limitation. Congress lifted the limiting phrase from the catch-all provision in 28 USC $\$ 377$, although it loosened the phrase by changing "necessary" to "necessary or appropriate." See note 15. The Josephson court therefore reasoned that all pre-1948 Supreme Court decisions in which the Court issued mandamus to a lower court could not serve as authority for an appellate court issuing mandamus. $218 \mathrm{~F} 2 \mathrm{~d}$ at 179.

However, the Court has continued to recognize the validity of its pre-1948 mandamus decisions. See, for example, Will v United States, 389 US at 95-96; Schlagenhauf, 379 US at 109-10; Beacon Theatres, 359 US at 511 n 20; Bankers Life \& Casualty, 346 US at 383-84. Moreover, the Court has explicitly ruled that the revision did not narrow the common law standards for the availability of mandamus. See $L a$ Buy, 352 US at 255 ("[t]he recodification of the All Writs Act in 1948 . . . did not affect the power of the Courts of Appeals to issue writs of mandamus in aid of jurisdiction"). The All Writs Act, therefore, does not appear to have altered the federal common law standards for issuing mandamus. For further analysis supporting this conclusion, see Note, $86 \mathrm{Harv}$ L Rev at $603 \mathrm{n} 42$ (cited in note 18).

45 247 US at 238 . The petitioner had originally brought suit in two counts against the executor of the decedent's estate for payment on a promise that the decedent had allegedly made to the petitioner. The first count alleged that the decedent had promised to pay $\$ 50,000$ for services rendered by the petitioner; the second count claimed the reasonable value for those services, also equal to $\$ 50,000$. Id.

16 Id at 240 .

47 253 US at 305-06.

4 Id at 305, 310-11. The district court had appointed a special auditor to hear and simplify some of the factual issues involved in a contract dispute over a coal delivery. Id at 304. The petitioner, the plaintiff in the dispute, in turn sought mandamus compelling the district judge to restore the case to the normal trial calendar, on the grounds that the order deprived the petitioner of his Seventh Amendment right to jury trial. Id at 305 . The Supreme Court rejected the petitioner's request, finding that the referral to an auditor did not deprive the petitioner of his right to jury trial, because the referral specifically stated that the auditor could not "finally determine any of the issues in this action." Id at 304, 310-11. The Court did state, however, that "if proceedings pursuant to the appointment of an auditor would deprive petitioner of his right to a trial by jury, the order should, as was said in [Simons], 'be dealt with now, before the plaintiff is put to the difficulties and the courts to the inconvenience that would be raised by' a proceeding 'that ultimately must be held to have been required under a mistake." Id at 305-06.

6 Skinner \& Eddy, 265 US at 96 . The petitioner had sued the United States in the Court of Claims for over $\$ 17,000,000$ in lost profits that the petitioner allegedly stood to 
reasoned that the non-suit was appropriate to avoid depriving the petitioner of his right to a jury trial of the same claim in a state court. ${ }^{\text {so }}$

The second and more important set of decisions is Beacon Theatres and Dairy Queen, which the Supreme Court decided in 1959 and 1962, respectively. In Beacon Theatres, the district court had decided to conduct a bench trial of the plaintiff's equitable claim first, which would have collaterally estopped jury trial resolution of the factual issues that were common to the defendant's legal counterclaim. ${ }^{51}$ The Supreme Court ruled that this collateral estoppel effect unconstitutionally deprived the defendant of its right to a jury trial, and granted mandamus to compel the district court to conduct the jury trial first. ${ }^{52}$ Just three years later, in Dairy Queen, the Supreme Court similarly granted a petitioner's request for a writ of mandamus. ${ }^{53}$ The district court had denied the petitioner's demand for a jury trial on the grounds that any legal issues raised by their claim were purely "incidental" to the equitable issues and thus could be resolved in a single bench trial. ${ }^{54}$ Again, the Supreme Court ruled that the petitioner was en-

gain on a contract to build and repair ships for the United States Emergency Fleet Corporation. Later, however, the petitioner moved for a non-suit on the action in the Court of Claims and then reinitiated substantially the same suit in a Washington state court. At first, the Court of Claims granted the non-suit, but after the suit in state court, the Court of Claims vacated the order of dismissal. Accordingly, the petitioner sought mandamus compelling the Court of Claims to reinstate the order of dismissal. Id at 91-92.

so Id at 96.

51359 US 500, 503-04 (1959). The plaintiff, Fox West Coast Theatres, Inc., had sought both declaratory relief and an injunction against the defendant, Beacon Theatres. The declaration Fox sought would have upheld the validity of contracts between Fox and certain movie distributors, under which Fox held the exclusive right to show certain movies for a stated period of time. The injunction Fox sought would have prevented Beacon Theatres from bringing an antitrust claim against Fox on these contracts. In turn, Beacon Theatres counterclaimed that the contracts violated the antitrust laws and demanded a jury trial on the factual issues raised by the antitrust dispute. The district court, however, liberally construed Fox's complaint seeking declaratory and injunctive relief to provide a basis for equitable jurisdiction. More significantly, the court ordered the bench trial of Fox's equitable claim to be conducted before the jury trial of Beacon Theatres' antitrust claim. Thus, the district court's order had the potential to deny Beacon Theatres a jury trial of the common factual issues, since the bench trial resolution of those issues would preclude any jury trial consideration of the same issues under the doctrine of collateral estoppel. Id at 502-04.

52 Id at 511 .

ss 369 US 469, 479-80 (1962).

st Id at 470. The plaintiffs, H.A. and H.F. McCullough, had a business partnership under the name of McCullough's Dairy Queen. They sued Dairy Queen for failing to make payments on a 1949 contract in which the McCulloughs had granted Dairy Queen the right to use the "Dairy Queen" trademark in Pennsylvania. Id at 473 . In a procedural setting very similar to that in Beacon Theatres, the McCulloughs sought (1) permanent injunctions 
titled to a jury trial of all the legal issues in its claim and so issued mandamus compelling the district court to conduct a jury trial first. ${ }^{.5}$

\section{B. Circuit Court Approaches}

The Supreme Court has left to the federal appellate courts the task of determining whether the above cases establish that the denial of jury trial is a "special circumstance" per se, or simply serve as examples of other recognized uses of mandamus. Federal courts of appeals have disagreed in interpreting these decisions. Most courts have held mandamus routinely available to compel the district court to recognize a petitioner's right to jury trial. The sole exception is the Seventh Circuit, which has limited the use of mandamus in this context to conditions of necessity.

1. The majority rule: Routine use of mandamus to compel jury trial.

Most courts of appeals have routinely allowed mandamus to compel jury trial. ${ }^{56}$ To justify this approach, they usually cite, without further reasoning, one or both of the above two sets of Supreme Court decisions as authority for treating the improper denial of jury trial as an "exceptional" circumstance that per se merits the remedy of mandamus. ${ }^{57}$ Some courts, however, have identified a pair of possible rationales for the above five Supreme Court decisions that might justify making mandamus available as a matter of course to compel jury trial.

The first rationale is that the constitutional nature of the right to a jury trial is an exceptional circumstance justifying the use of mandamus. A number of circuit courts, either implicitly or explicitly, have interpreted the Supreme Court decisions as authorizing

preventing Dairy Queen from using and profiting from the "Dairy Queen" trademark and (2) an accounting for money owed plaintiffs for past use of the trademark. Id at 475 . Dairy Queen denied that they had breached the contract and demanded a jury trial.

ss Id at $479-80$.

s8 See cases cited in note 4.

87 A typical example of the depth of analysis given to this issue is Lee Pharmaceuticals, in which the court justified the use of the extraordinary writ as follows: "It is well-settled that a writ of mandamus is an appropriate means to redress the incorrect denial of a jury trial." 526 F2d at 1116 (citing Beacon Theatres). See also Vorpahl, 695 F2d at 319 (citing Dairy Queen, Beacon Theatres) ("The remedy of mandamus in determining the right to a jury trial is firmly settled."); Jewell v Ohio River Co., 431 F2d 691, 692 (3d Cir 1970) (citing Dairy Queen, Beacon Theatres) ("Mandamus is appropriate to require a district court to grant petitioner a jury trial."). 
mandamus to protect the petitioner's important constitutional right to trial by jury. ${ }^{58}$ For example, in Black $v$ Boyd, a case decided before Beacon Theatres and Dairy Queen, the Sixth Circuit determined that "it was the exceptional circumstances involved in [Simons], namely the deprivation of the constitutional right of trial by jury, that accounted for the issuance of the writ."'so And in General Tire \& Rubber Co. $v$ Watkins, the Fourth Circuit, while denying the petition for mandamus on other grounds, cited both Beacon Theatres and Dairy Queen for the proposition that mandamus would have been an appropriate remedy "since the question presented pertains to a denial of the constitutional right to trial by jury." 60

The second rationale is that mandamus is justifiable to avoid the inconvenience of an unnecessary trial. Some circuit courts have interpreted the Supreme Court authority as permitting mandamus on grounds of administrative efficiency-to avoid conducting a trial that would later be overturned on appeal anyway. ${ }^{61}$

2. The Seventh Circuit rule: "Necessity" required for mandamus to compel jury trial.

The one court of appeals that has more narrowly construed the Supreme Court authority is the Seventh Circuit. In First $\mathrm{Na-}$ tional Bank of Waukesha $v$ Warren, the court refused to grant mandamus to reverse a district court's order denying a jury trial. ${ }^{62}$

\footnotetext{
ss See, for example, Filmon Process Corp. $v$ Sirica, 379 F2d 449, 451 (DC Cir 1967) ("Other circuit courts of appeals have taken the view that the denial of a jury trial in contravention of a party's constitutional rights automatically presents 'such an exceptional situation as to call for the issuance of mandamus to review the ruling' [quoting Black $v$ Boyd, 248 F2d 156, 160 (6th Cir 1957)]."); Higgins v Boeing Co., 526 F2d 1004, 1006 (2d Cir 1975) (per curiam) (citing Beacon Theatres) ("Our power to preserve the important right to trial by jury ... by mandamus is clear."); Owens-Illinois, Inc. $v$ U.S. Dist. Court for the Western Dist. of Washington, 698 F2d 967, 969 (9th Cir 1983) (per curiam) (citing Dairy Queen) ("Where the constitutional right to a jury trial is drawn in question, mandamus is an appropriate remedy."). See also In re Union Nacional de Trabajadores, 502 F2d 113, 116 n 1 (1st Cir 1974) ("It would appear that the lower court would be equally unlawful . . . in denying either a constitutional or a statutory right to a jury trial, . . . at least insofar as it would influence a decision to grant mandamus.").

so 248 F2d at 161.

so 331 F2d 192, 194 (4th Cir 1964).

-2 See, for example, Whittel v Roche, 88 F2d 366, 369 (9th Cir 1937).

62 796 F2d 999, 1006 (7th Cir 1986). The plaintiff, the FDIC, acting in its corporate capacity on behalf of a defunct Milwaukee bank, sued the First National Bank of Waukesha (FNB) on theories of fraud and unjust enrichment. The FDIC alleged that the FNB had induced the Milwaukee bank to loan money to a FNB depositor that FNB knew he could never repay. FNB in turn had allegedly used the loan money to repay a fraudulent check drawn by the depositor against his FNB account, a check the Bank had certified despite the
} 
In contrast to the opinions of other circuit courts, the First $\mathrm{Na}$ tional Bank opinion spends only a page considering the tangled arguments as to whether the petitioner was entitled to jury trial on the merits. ${ }^{63}$ The court devoted most of the opinion to what it considered to be the real issue-whether mandamus was an appropriate remedy in the first place. ${ }^{64}$ Ultimately, the court held that mandamus was inappropriate in this case because it was not a situation of necessity - the petitioner could appeal the district court order at the conclusion of the trial. ${ }^{65}$

To square this holding with Supreme Court precedent, the First National Bank court narrowly interpreted Simons, Beacon Theatres, and Dairy Queen as cases of necessity. The Supreme Court, the Seventh Circuit argued, had granted mandamus because later appeals would have been unable to cure the collateral estoppel effects of the denial of jury trial..$^{66}$ The Seventh Circuit dismissed outright the notion that the constitutional nature of the right to jury trial itself justified mandamus. ${ }^{67}$ Furthermore, the Seventh Circuit posited that the inconvenience rationale suggested in Simons "has been rejected in subsequent cases too numerous to count." ${ }^{.68}$ Finally, the First National Bank court asserted that the Supreme Court in more recent years had overruled the supervisory strain of mandamus recognized in La Buy. To the extent that Beacon Theatres and Dairy Queen may have represented supervisory mandamus, these decisions were no longer applicable. ${ }^{69}$ If the district court had wrongly denied the petitioner's right to jury trial or, for that matter, had committed any other appealable error, the Seventh Circuit concluded that mandamus was available only in the absence of another effective remedy for that error. ${ }^{70}$

fact that the depositor had no money in the account. Before trial, the FDIC elected to drop its fraud theory and proceed only on the theory of unjust enrichment, in order to avoid a jury trial. The FNB then petitioned the Seventh Circuit for a writ of mandamus. The bank argued that the FDIC's claim for money damages under an unjust enrichment theory was at best a guise for a fraud claim, a common law theory requiring resolution by jury trial. Id at 999-1000.

es Id at 1000-01.

64 Id at 1001-06.

as Id at 1006.

${ }^{68}$ Id at 1002-04.

${ }^{87}$ Id at 1002 ("Much federal litigation involves constitutional rights, but the nature of the right does not dictate whether review comes in mid-course or at the end of the district court's proceedings.").

8 Id at 1003.

89 Id at 1004-06.

70 Id at 1006. In the five years since First National Bank, the Seventh Circuit has slightly modulated its strict rule. In Maloney v Plunkett, 854 F2d 152, 153 (7th Cir 1988), 


\section{Refining the Use of Mandamus to Comped Jury Trial}

The circuit split created by the Seventh Circuit in First $\mathrm{Na}$ tional Bank is a broad one. Most circuits routinely allow mandamus to compel a jury trial, while the Seventh Circuit allows it only in cases of necessity. This Section demonstrates that neither of these approaches faithfully reflects Supreme Court precedent, and argues that the best approach is to allow mandamus to compel jury trial in the same categories of cases that the Court has allowed in other contexts.

\section{A. The Overly Broad Majority Rule}

Two policy considerations counsel against expanding the availability of mandamus beyond what has already been recognized by the Supreme Court. First, the Supreme Court has pointed out that any petition for mandamus has " the unfortunate consequence of making the [district court] judge a litigant, obliged to obtain personal counsel or to leave his defense to one of the litigants [appearing] before him' in the underlying case."71 The awkwardness of making a federal judge a frequent party to appellate litigation thus argues strongly against the routine availability of mandamus as an interlocutory appellate remedy in any context.

Second, and more importantly, any expansion in the use of mandamus runs counter to the Final Decisions Rule and its opposition to interlocutory appeals and piecemeal litigation. Policy judgments about administrative efficiency cannot provide a sound basis for establishing new strains of mandamus. Congress expressed its disapproval of such judgments when it enacted the Fi-

the court granted mandamus vacating a district court order that would have discharged the selected jury, ordered the selection of a new jury, and forbidden the litigants' use of peremptory challenges in the selection. In granting the petition, the court acknowledged that "ordinarily the inconvenience, lost time, and sunk costs of such further proceedings as could have been avoided by [mandamus] are not considered the kind of irremediable harm that will satisfy the stringent requirements for issuing a writ of mandamus." Id at 154-55. But the court then added that this rule was not "unwavering" and that the district court order had imposed such "exceptional burdens . . . on the orderly resolution of this lawsuit" as to justify mandamus. Id at 155-56. Strictly speaking, Maloney was not a case in which the Court of Appeals issued mandamus to prevent the petitioner from being wrongly deprived of jury trial. In fact, the Maloney court admitted that the judge had not "den[ied] either side its Seventh Amendment right to trial by jury, but he did deny a statutory [right] incident to jury trial . . . ." Id at 154. However, the looser standard announced by Maloney might be applicable to cases like First National Bank; the precise nature of the Seventh Circuit doctrine is presently unclear.

${ }^{71} \mathrm{Kerr}, 426$ US at 402 (quoting Bankers Life \& Casualty, 346 US at 384-85 (quoting Fahey, 332 US at 260)). 
nal Decisions Rule in 1789. Moreover, although the Final Decisions Rule has never been interpreted to preclude the development of common law exceptions to the rule against interlocutory appeals, administrative efficiency arguments depend on open empirical questions. It is impossible to know whether making mandamus available to catch district court errors early will, on balance, prevent much unnecessary litigation or simply clog the dockets of the appellate courts with frivolous interlocutory appeals. Indeed, courts have invoked administrative efficiency to support decisions expanding or contracting the availability of mandamus. ${ }^{72}$

In view of these considerations, the majority approach, which routinely approves of mandamus to order a jury trial, should be closely scrutinized. Courts embracing that approach have relied on the constitutional nature of the right to a jury trial and on administrative efficiency. Neither rationale justifies the courts' expansive use of mandamus.

1. The constitutional nature of the right to jury trial as an invalid basis for mandamus.

Supreme Court authority provides exceedingly thin support for the interpretation that the nature of the right to trial by jury constitutes a special circumstance that per se justifies mandamus. In Beacon Theatres, the Court, after establishing that the petitioner was entitled to jury trial on the merits, determined in one sentence that mandamus rather than a normal appeal was the appropriate remedy: "Whatever differences of opinion there may be in other types of cases, we think the right to grant mandamus to require jury trial where it has been improperly denied is settled."73 While this sentence obviously offered no explicit basis for its conclusion, the Court did include a footnote that cited a number of Supreme Court and circuit court cases as authority for the above

\footnotetext{
72 Compare Canister Co. v Leahy, 191 F2d 255, 257 (3d Cir 1951) ("Appeal, after an abortive trial to the court, would be clearly inadequate remedy."), and Eldredge $v$ Gourley, 505 F2d 769, 770 (3d Cir 1974) (citing Beacon Theatres for the proposition that mandamus would allow "the issues between these parties [to] be settled in one suit"), with some of "the vices of an interlocutory appeal" recited by the Seventh Circuit:

How many future litigants will seek interlocutory review? ... If most decisions by district courts are correct, then the costs of reviewing the many cases (including the mistakes introduced by hasty appellate review) exceed the costs of allowing the few mistaken decisions to go uncorrected until after final judgment.

First National Bank, 796 F2d at 1003.

73 359 US at 511.
} 
proposition. ${ }^{74}$ And in Dairy Queen, the Court added some credence to this interpretation of Beacon Theatres, justifying the issuance of mandamus as follows: "Our decision reversing that case ... emphasizes the responsibility of the Federal Courts of Appeals to grant mandamus where necessary to protect the constitutional right to trial by jury."'7s

But neither of these decisions provides a sound basis for concluding that the denial of a constitutional right, without more, is an exceptional circumstance justifying mandamus. Given that the federal courts traditionally have determined the availability of mandamus based on the procedural context of the error, rather than on the nature of the substantive right at issue, it would be anomalous to read Beacon Theatres and Dairy Queen to hinge on the constitutional nature of the right to a jury trial.

Indeed, each of the three categories of mandamus described above-mandamus under conditions of necessity, supervisory mandamus, and advisory mandamus-relies on the procedural context of the error. In defining the limits of advisory mandamus, for example, the Court in Schlagenhauf cautioned that although it sanctioned the use of mandamus to overrule the district court's incorrect interpretation of Rule 35, the commission of such an error in the future would not necessarily justify mandamus: "This [use of mandamus] is not to say, however, that, following the setting of guidelines in this opinion, any future allegation that the District Court was in error in applying these guidelines to a particular case makes mandamus an appropriate remedy." "76 Thus, Schlagenhauf has been interpreted to authorize advisory mandamus to settle "new and important" legal issues and not to authorize mandamus to overturn improper interpretations of FRCP 35 or of the Federal Rules in general. ${ }^{77}$ The nature of the substantive right at issue is simply irrelevant for purposes of determining the availability of mandamus. As the Seventh Circuit explained in First National Bank, "much federal litigation involves constitutional rights, but the nature of the right does not dictate whether review comes in

${ }^{74}$ Id at 511 n 20. Significantly, this footnote included a citation of Black, the Sixth Circuit decision that identified the constitutional nature of the right to trial by jury as the rationale for the remedy of mandamus. The note also cited the Supreme Court decisions in Simons, Peterson, and La Buy.

${ }^{73} 369$ US at 472.

76379 US at 112.

77 See Comment, 44 Tenn L Rev at 149-50 (cited in note 12); Note, 86 Harv L Rev at 613-19 (cited in note 18). 
mid-course or at the end of the district court's proceedings."78

In the absence of explicit affirmation by the Court, there is little reason to presume that the constitutional nature of the right to trial by jury justifies mandamus. Nor has the Court relaxed the traditional mandamus standards in cases where the petitioner is asserting other constitutional rights. For instance, in Helstoski $v$ Meanor, a former congressman sought mandamus to reverse an indictment that he alleged violated the Speech or Debate Clause. ${ }^{79}$ Without addressing the merits of the petitioner's claim, the Court refused to issue the writ, because the defendant had an alternative path of appellate review. ${ }^{\mathbf{8 0}}$ Given the policy of the Final Decisions Rule that mandamus should not automatically be available, and that the Seventh Amendment right to jury trial has not even been incorporated through the Fourteenth Amendment, ${ }^{81}$ the nature of the right to jury trial alone cannot justify mandamus.

\section{2. "Inconvenience" as an invalid basis for mandamus.}

The Supreme Court has more explicitly endorsed the inconvenience rationale in Simons, Peterson, and Skinner \& Eddy. In Simons, the Court allowed the issuance of mandamus because the denial of jury trial was "an order that should be dealt with now, before the plaintiff is put to the difficulties and the Courts to the inconvenience that would be raised by a severance that ultimately must be held to have been required under a mistake."82 Two years later, in Peterson, the Supreme Court affirmed the Simons reasoning in dicta by quoting the above passage. ${ }^{83}$ And, in Skinner \& $E d d y$, the Court similarly found that the "useless waste of time and effort to enforce a trial" justified using mandamus. ${ }^{84}$

Subsequent Supreme Court decisions, however, have rejected inconvenience as a rationale for permitting mandamus. In Roche $v$ Evaporated Milk Association, the petitioners for mandamus, who were challenging the validity of their grand jury indictment, argued that failure to grant mandamus would subject them to a po-

$78796 \mathrm{~F} 2 \mathrm{~d}$ at 1002.

79 442 US 500, 504-05 (1979).

so Id at 506.

81 See Walker $v$ Sauvinet, 92 US 92, 92-93 (1875) (jury trial at common law was neither part of due process nor a privilege or immunity of citizenship).

82247 US at 239. The Court also noted that this use of mandamus satisfied the traditional standards because "the order may be regarded as having repudiated jurisdiction of the first count . . . ." Id at 240.

ss 253 US at $305-06$.

265 US at 96. 
tentially unnecessary trial before appellate review of the indictment. ${ }^{85}$ The Court squarely rejected this ground for mandamus:

[T] hat inconvenience is one which we must take it Congress contemplated in providing that only final judgments should be reviewable. Where the appeal statutes establish the conditions of appellate review, an appellate court cannot rightly exercise its discretion to issue a writ whose only effect would be to avoid those conditions and thwart the Congressional policy against piecemeal appeals in criminal cases. ${ }^{86}$

Later, in Bankers Life \& Casualty Co. $v$ Holland, the Court again rejected the argument that mandamus was appropriate "to prevent 'judicial inconvenience and hardship' occasioned by appeal being delayed until after final judgment." to issue the writ would "give rise to a myriad of legal and practical problems as well as inconvenience to both courts," the Court again observed that "Congress must have contemplated those conditions in providing that only final judgments are reviewable."

In short, the Supreme Court in the last sixty years has rejected administrative efficiency arguments like those made in Simons, Peterson, and Skinner \& Eddy because they permit judicial second-guessing of the Final Decisions Rule. Even just one year after Dairy Queen, in Schlagenhauf, the Court noted "that the writ is not to be used as a substitute for appeal, even though hardship may result from delay and perhaps unnecessary trial." Thus, although the Court has not done so formally, it has effectively overruled all three of these decisions to the extent that they represent the proposition that mandamus will lie to prevent the "inconvenience" to petitioners and courts of awaiting an appeal from a final judgment.

319 US 21, 30 (1943).

se Id.

346 US 379, 383 (1953).

*3 Id. See also United States Alkali Export Ass'n v United States, 325 US 196, 202 (1945), a certiorari case in which the Supreme Court expounded upon the doctrine applicable to all extraordinary writs:

It is evident that hardship is imposed on parties who are compelled to await the correction of an alleged error at an interlocutory stage by an appeal from a final judgment. But such hardship does not necessarily justify resort to certiorari or other of the extraordinary writs as a means of review.

a. 379 US at 110. 
B. The Overly Narrow Seventh Circuit Rule

The Seventh Circuit's rule of limiting mandamus to cases of necessity is attractive as a bright-line rule that clearly satisfies the Final Decisions Rule. It is not faithful, however, to the Supreme Court's decisions in Simons, Beacon Theatres, and Dairy Queen, and it does not comport with broader Supreme Court precedent on the availability of mandamus. The Seventh Circuit is correct that neither the constitutional nature of the right to jury trial nor potential inconvenience to the petitioner and to the courts will justify the broad availability of mandamus to compel jury trial. The narrow rule that mandamus is available only to compel jury trial in cases of necessity, however, depends on two further arguments made explicitly by the Seventh Circuit in First National Bank: (1) that supervisory mandamus is effectively dead; and (2) that Simons, Beacon Theatres, and Dairy Queen were themselves cases of necessity. This narrow interpretation also depends on a third implicit argument of the Seventh Circuit: that, even if Simons, Beacon Theatres, and Dairy Queen are cases of necessity, such necessity is the only category of mandamus available to compel jury trial. None of these three arguments withstands analysis.

1. The continued validity of "supervisory" mandamus.

In First National Bank, the Seventh Circuit prematurely announced the death of the supervisory strand of mandamus introduced by the Supreme Court in La Buy. The First National Bank court acknowledged that the Supreme Court may have used mandamus in both Beacon Theatres and Dairy Queen as a means of the supervisory control authorized by the Supreme Court in $L a$ Buy. ${ }^{90}$ After all, the Court in Beacon Theatres had cited La Buy in support of its conclusion that "the right to grant mandamus to require jury trial where it has been improperly denied is settled." The Seventh Circuit contended, however, that La Buy and its use of mandamus for supervisory control was "defunct." concluded the Seventh Circuit, "[t]o the extent [that Beacon Theatres and Dairy Queen] stand for the proposition that appellate courts should issue 'supervisory' mandamus to spare the par-

so 796 F2d at 1004.

91359 US at $511 \mathrm{n} 20$.

92796 F2d at 1004 . The court conceded that the Supreme Court had not formally overruled $\mathrm{La}$ Buy, but added that "[a]lthough the Court has not yet erected the tombstone, it has ordered flowers." Id. 
ties the need to go through the trial and present a claim of error on appeal, they have been undermined."

The Seventh Circuit was indeed correct that Beacon Theatres and Dairy Queen cannot serve as examples of supervisory mandamus. Neither case contains any evidence that the Court was correcting a systematic error by the district court. In Beacon Theatres, the district judge had been, at worst, guilty of following Supreme Court precedent, which the Court overruled in Beacon Theatres because of a change in standards under the Federal Rules of Civil Procedure. ${ }^{94}$ This behavior contrasts sharply with that of Judge La Buy, who had ignored repeated warnings from the Seventh Circuit about his practice of referring cases to a special master. ${ }^{95}$ Similarly, in Dairy Queen, there was no evidence of chronic abuse.

Nevertheless, supervisory mandamus as defined by $L a B u y$ should still be available to correct a district court's chronic disregard of a litigant's right to a jury trial, even if Beacon Theatres and Dairy Queen are not specific examples. In the thirty years since $L a B u y$, the Supreme Court has indeed imposed some bounds on the use of supervisory mandamus by the appellate courts-limits that are to be expected in light of the Final Decisions Rule and the traditional constraints on mandamus. Contrary to the Seventh Circuit's arguments in First National Bank, the Court has not overruled $L a B u y$, explicitly or implicitly. ${ }^{96}$

In particular, the Seventh Circuit relied on the Supreme Court's decision in Will $v$ United States, ${ }^{97}$ the most important post-La Buy case in which the Supreme Court addressed the use of supervisory mandamus. ${ }^{98}$ In Will, the district court had ordered the prosecuting attorney to submit a detailed and burdensome bill of particulars. The appellate court had ruled that this bill was in

93 Id at 1006.

24 359 US at 505-09.

${ }^{95} \mathrm{La} \mathrm{Buy}, 352$ US at 258.

96 See, for example, Will v Calvert Fire Insurance, 437 US 655 (1978), and Kerr v U.S. Dist. Court for the Northern Dist. of California, 426 US 394 (1976), both of which the First National Bank court noted as examples of the Court's disapproval of La Buy. 796 F2d at 1005-06. In Calvert Fire Insurance, the Court noted only that its decision in Will v United States, 389 US 90, 98 n 6 (1967), had admonished against an expansive reading of $L a$ Buy. Will v Calvert Fire Insurance, 437 US at 665-66 n 7. The Calvert Fire Insurance Court did not explicitly overrule $L a B u y$, however, and the imposition of limitations on $L a B u y$ is consistent with the warnings in La Buy itself against "the indiscriminate use of prerogative writs." La Buy, 352 US at 255. See also Note, 86 Harv L Rev at 602-13 (cited in note 18); Comment, 44 Tenn L Rev at 147-49 (cited in note 12).

97389 US 90.

so First National Bank, 796 F2d at 1005. 
fact an improper discovery device and had granted mandamus to the government reversing the district court order. ${ }^{99}$ The Supreme Court ruled that mandamus was not the appropriate remedy for this type of error. Although such a use of the writ could certainly fit into a broad definition of supervision, the government had not demonstrated that the defendant "had adopted a deliberate policy in open defiance of the federal rules in matters of pretrial criminal discovery." 100 Most importantly, instead of overruling La Buy, the Will Court reaffirmed a narrow interpretation of $L a$ Buy as a case "where a district judge [had] displayed a persistent disregard" for the Federal Rules of Civil Procedure. ${ }^{101}$ First National Bank thus read the Supreme Court precedent too narrowly.

2. The Seventh Circuit's misinterpretation of Simons, Beacon Theatres, and Dairy Queen.

In First National Bank, the Seventh Circuit interpreted the Supreme Court decisions in Simons, Beacon Theatres, and Dairy Queen as cases of necessity-in which the petitioners would have lost their right to jury trial if the Court had waited until the end of the proceeding to order a jury trial. ${ }^{102}$ In Simons, for example, the Seventh Circuit argued that the district court's judgment on the plaintiff's equitable claim could have collaterally estopped a subsequent jury trial of the same factual issues in plaintiff's legal claim. ${ }^{103}$ Because, the Seventh Circuit asserted, the court's judgment on the equitable claim would be "invulnerable on appeal," the plaintiff would never have received a jury trial of the factual issues in her claim. ${ }^{104}$ The Seventh Circuit's analysis of Beacon Theatres and Dairy Queen similarly emphasized the collateral estoppel effect on the factual issues in the legal claims if mandamus were not available. ${ }^{105}$

In the Seventh Circuit's view, the collateral estoppel effect of the bench trial resolution of the equitable claims in all three of these cases made them cases of necessity because the common factual findings would be "invulnerable on appeal."106 The Seventh Circuit further noted that certain language in the Dairy Queen

\footnotetext{
92389 US at 91-94.

$100 \mathrm{Id}$ at 102.

101 Id at 96.

102796 F2d at 1002-04.

103 Id at 1003-04.

104 Id at 1003 .

${ }^{108}$ See id at 1004-05.

108 Id at 1003-04.
} 
opinion hinted at this necessity interpretation of both Beacon Theatres and Dairy Queen, reasoning that both opinions had established "the responsibility of the Federal Courts of Appeals to grant mandamus where necessary to protect the constitutional right to trial by jury."10z

It is true that such "foreclosure of review" as hypothesized by the Seventh Circuit would constitute a classic instance of necessity justifying mandamus. But the Seventh Circuit's premise that, in all three cases, the disposition of factual issues during the bench trial would be "invulnerable on appeal" is questionable. The opinion simply provides no authority for this anomalous constraint on the power of the appellate courts.

In fact, there is Supreme Court precedent holding that an appellate court may order a complete retrial of all the factual issues common to legal and equitable claims, without residual collateral estoppel effects. In Lytle $v$ Household Manufacturing, Inc., the plaintiff had brought both a Title VII and a $\S 1981$ claim, but the district court had dismissed the $\S 1981$ claim and had resolved the Title VII claim with a bench trial. ${ }^{108}$ In reversing the district court's dismissal of the $\S 1981$ claim, the Supreme Court also held that the petitioner was entitled to a jury trial of all the factual issues in the $\S 1981$ claim without any collateral estoppel effect from the bench trial resolution of the same issues in the Title VII claim:

Our conclusion is consistent with this Court's approach in cases involving a wrongful denial of a petitioner's right to a jury trial on legal issues. In such cases, we have never accorded collateral-estoppel effect to the trial court's factual determinations. Instead, we have reversed and remanded each case in its entirety for a trial before a jury. ${ }^{108}$

Thus, contrary to the Seventh Circuit's interpretation, collateral estoppel effects do not render these mandamus decisions cases of necessity.

\footnotetext{
107 Id at 1004, quoting Dairy Queen, 369 US at 472 (emphasis added).

$108110 \mathrm{~S}$ Ct 1331, 1334-35 (1990).

100 Id at 1337 (citing Meeker v Ambassador Oil Corp., 375 US 160 (1963) (per curiam)); Tull $v$ United States, 481 US 412 (1987); Granfinanciera, S.A. v Nordberg, 492 US 33 (1989)). See also Simons, 247 US at 239, where Justice Holmes admitted that even if the Supreme Court did not grant mandamus, an appellate court might later overturn the results of the bench trial.
} 
3. The other available categories of mandamus.

The most serious flaw with the Seventh Circuit's argument is its assumption that, even if Simons, Beacon Theatres, and Dairy Queen served as examples of necessity, this condition constitutes the only circumstance under which mandamus is appropriate to compel jury trial. As noted above, besides necessity, the Court has recognized the use of advisory and supervisory mandamus, as well as mandamus in other exceptional circumstances. ${ }^{110}$ Thus, the conclusion that the petitioners had no other effective remedy for the denial of jury trial would not, even if true, by itself support the proposition that mandamus should be limited to such cases of necessity.

C. A Proposed Standard: Use of the Traditionally Recognized Categories of Mandamus to Compel Jury Trial

As demonstrated above, both sides of the circuit split examined by this Comment reach unsatisfactory conclusions. The majority of the circuits routinely grant mandamus to order jury trials. But this expansive use of mandamus is inconsistent with Supreme Court precedent. Subsequent decisions have overruled the Court's earlier cases granting mandamus to order jury trial on grounds of administrative efficiency, and there is no support for considering the constitutional nature of the right in determining the availability of the writ. The Seventh Circuit approach is more narrow, confining the use of mandamus to cases of necessity. But this narrow use of mandamus is also inconsistent with Supreme Court precedent. The Court's approval of supervisory mandamus has never been overruled, Simons, Beacon Theatres, and Dairy Queen are not cases of necessity, and those three cases do not preclude the traditional categories of mandamus.

Supreme Court precedent requires rejection of both sides of the circuit split; instead, the same categories of mandamus should be available to order jury trial as are used to correct any other error. This conclusion is consistent with the view that the availability of mandamus is determined by the procedural context of the error, not by the nature of the substantive right at issue. It is also consistent with the policy expressed in the Final Decisions Rule of avoiding piecemeal litigation.

The proposed standard would permit the use of mandamus in 
cases of necessity as well as in exceptional circumstances, including supervisory and advisory mandamus. If, for example, mandamus were the only effective remedy because the petitioners could not later appeal the denial of a jury trial, mandamus would be available under the necessity category. Or, if the district court has a history of improperly denying jury trials, supervisory mandamus would be available to remedy this abuse. If the denial of the jury trial raises important issues of first impression about the jury trial right, advisory mandamus might be available. Finally, other exceptional circumstances, such as the issues of "public importance" raised in Republic of Peru, might also justify the use of mandamus. ${ }^{111}$

There remains the task of categorizing the Court's decisions in Beacon Theatres and Dairy Queen. While Simons, Peterson, and Skinner \& $E d d y$ are doubtful authority for the use of mandamus to compel jury trial, the Supreme Court has not similarly cast doubt on Beacon Theatres and Dairy Queen. If they do not fit an accepted category of mandamus, they support the conclusion that the denial of a jury trial is not subject to the traditional strict standards for the availability of mandamus. However, the best interpretation of Beacon Theatres and Dairy Queen is that they merely demonstrate the advisory use of mandamus that the Supreme Court explicitly recognized one year later in Schlagenhauf. In all three cases-Beacon Theatres, Dairy Queen, and Schlagenhauf-the Supreme Court was deciding important issues of first impression about the construction and application of the Federal Rules of Civil Procedure. ${ }^{112}$ Admittedly, in both Beacon Theatres and Dairy Queen, the Court held that a federal court sitting in equity could not resolve factual issues relating to a litigant's legal claim and thereby preclude the later resolution of those issues before a jury. ${ }^{113}$ But the similarity of these holdings does not refute this novel interpetation. Each case presented a different aspect of this basic principle, so that each may properly be understood as resolving issues of first impression.

11 See text at notes 26-28.

11 Beacon Theatres, 359 US at 509 (court was reevaluating scope of equitable jurisdiction "in the light of the liberal joinder provisions of the Federal Rules"); Dairy Queen, 369 US at 471-72 (court ruled that Federal Rules did not displace earlier holding that "the right to trial by jury of legal claims must be preserved" (footnote omitted)); Schlagenhauf, 379 US at 109 ("We granted certiorari to review undecided questions concerning the validity and construction of Rule 35.").

113 Beacon Theatres, 359 US at 510-11; Dairy Queen, 369 US at 472-73. 
In Beacon Theatres, the court of appeals had invoked the traditional rule that a court sitting in equity could retain jurisdiction over a later legal counterclaim by the defendant, if the plaintiff alleged that the defendant was threatening to harass the plaintiff with a "multiplicity of lawsuits."114 The Supreme Court concluded, however, that the trial court had no discretion to shift the entire case to the equitable side of its docket because the liberal joinder provisions of Rule 18 permitted the district court to join both legal and equitable claims in the same action. ${ }^{115}$ In contrast, the district court in Dairy Queen had attempted to invoke a "clean up" doctrine, which would have allowed the Court to treat the plaintiff's entire claim as equitable if the legal issues raised by the claim were only incidental to the equitable ones, in order to justify conducting a bench trial first. ${ }^{116}$ This time the Supreme Court concluded that the liberal joinder provisions of the new Rule 18 did not overrule its earlier holding ${ }^{112}$ that a court of equity could not so treat the plaintiff's claim, even if the complaint presented both legal and equitable issues. ${ }^{118}$

In short, Beacon Theatres and Dairy Queen each resolved "new and important problems" about the interaction of law and equity under the recently adopted Federal Rules. The fact that both opinions extensively discussed the merits of the petitioner's claims and only briefly reviewed the mandamus issue reinforces this interpretation. In Beacon Theatres, the Court particularly emphasized the novelty of the issue before it, acknowledging that, prior to the federal rules, the district court "traditionally" could have invoked equitable principles "to take jurisdiction and settle the case in one suit." 119 It is thus a fair reading that these cases exemplified the advisory mandamus that the Supreme Court more formally recognized one year later in Schlagenhauf.

\section{ConClusion}

All the categories of mandamus should be available to compel jury trial. If the newer exceptional categories of supervisory and advisory mandamus are properly constrained to the procedural contexts that the Court found significant in $L a$ Buy and Schlagenhauf, this standard would still reject most of the typical petitions

\footnotetext{
124359 US at 506.

128 Id at 508.

126369 US at 470.

${ }_{117}$ See Scott v Neely, 140 US 106 (1891).

11 Dairy Queen, 369 US at 471-72.

119359 US at 506.
} 
for mandamus. Indeed, if the Seventh Circuit had applied this standard in First National Bank, it could have denied the writ of mandamus because the facts of the case did not indicate that the district court had a history of misconstruing fraud claims as unjust enrichment claims or that this run-of-the-mill monetary dispute presented any "novel and important" legal issues to resolve.

The strength of this rather unexciting conclusion-that the same categories of mandamus are available to compel jury trial as to correct any other kind of district court error-is that it avoids the "vices of interlocutory appeal" that the Seventh Circuit decried in First National Bank while remaining faithful to the Supreme Court authority on mandamus. Ensuring that mandamus remains as "extraordinary" a remedy for these errors as for all other errors avoids the awkwardness of making the district judge a frequent party to a legal action, deters the inevitable frivolous appeals that would arise from the routine availability of the writ, and satisfies the congressional policy disfavoring interlocutory appeals embodied in the Final Decision Rule. This regime resolves the tension between the Final Decisions Rule and the All Writs Act in a manner that is most faithful to Supreme Court precedent. 
